\title{
CONTRADICTIONS IN THE RELATIVE CHRONOLOGY: ARCHAEOLOGICAL AND RADIOCARBON DATING
}

\author{
Werner E Stöckli \\ Institut für Ur- und Frühgeschichte und Archäologie der Römischen Provinzen, Universität Bern, Bernastrasse 15A, CH-3005 \\ Bern, Switzerland. Email: werner.stoeckli@sfu.unibe.ch.
}

\begin{abstract}
When comparing dendrodates and radiocarbon dates, I advocate using the mean value for archaeologically defined data series, as in the usual case, the correct dating is always more precise than the calibrated areas. However, in the extreme gradient of the calibration curve, we must consider the errors. Based on the Corded Ware from the Tauber basin, I put forward a first example in which a contradiction between the archaeological and ${ }^{14} \mathrm{C}$ dating occurs. If one cleanly separates the older measurements from Köln and the younger ones from Heidelberg, the contradiction towards the archaeological dating is canceled out when only the younger Heidelberg dates are taken into account. Regarding the Early Bronze Age, I shall first deal with the cemetery at Singen and will show, using the typology and the horizontal distribution of the graves, how outliers can be identified, thus narrowing the range for dating of the cemetery. The comparison of 2 archaeologically contemporaneous cemeteries in the Neckar basin (Rottenburg and Gäufelden) again results in contradictions between the archaeological and ${ }^{14} \mathrm{C}$ dating. In this case, the contradictions cannot be solved without any new dating measurements. It is recommended that these should be carried out by at least 2 laboratories. Finally, some recommendations are given to archaeologists. In my opinion, ${ }^{14} \mathrm{C}$ dates that are archaeologically unsuitable should be used to check the findings and the archaeologicaltypological classification. The contradictions should be reported immediately to the ${ }^{14} \mathrm{C}$ laboratory, so that any possible experimental errors can be identified.
\end{abstract}

\section{INTRODUCTION}

Firstly, I shall deal with German and Swiss finds from the time between 2750 and 1550 BC (Figure 1). This is the period of the Corded Ware, the Bell Beaker, and the Early Bronze Age. I shall then proceed to discuss the contradictions between archaeo-typological and radiocarbon dating. The ${ }^{14} \mathrm{C}$ dates concern only dates taken from bone samples.

In central Europe, the relative chronology of the Bronze Age and the Neolithic Age was settled in the 20th century. However, the chronology of the Corded Ware, the Bell Beaker, and the Early Bronze Age is still in dispute today. Here, the interpretation of ${ }^{14} \mathrm{C}$ dates plays an important role. Depending on the opinion of the archaeologists, contradictions can result between archaeo-typological and ${ }^{14} \mathrm{C}$ dating.

The main reason for the problems is the lack of dendrodates in large parts of central Europe, as well as the gap in the dendrochronological curve between about 2420 and 1880 BC in Switzerland and the German regions of Lake Constance (Figure 2). It is because of this gap that the important Early Bronze Age settlements of Zurich Mozartstrasse were dated incorrectly. From a typological point of view, one could notice that something was wrong, but in Switzerland the archaeologists just could not imagine the dendrodates of Zurich Mozartstrasse being incorrect. A solution was found in 2001 and the settlements of Mozartstrasse were put back by $250 \mathrm{yr}$ with the help of ${ }^{14} \mathrm{C}$ dating (Conscience 2001).

Using ${ }^{14} \mathrm{C}$ dating, the sequence Corded Ware-Bell Beaker-Early Bronze Age was proven in principle by Wolfgang Pape (Pape 1979). He made cumulated bell-shaped gauss curves in the form of a histogram. The main emphasis of the 3 cultural stages can be seen in clear sequence, but the dates overlap strongly (Pape 1979:29). This is a welcome affirmation for archaeologists, since it allows them to synchronize as many cultural phenomena as possible. I personally represent an opposite position, as the experiences I have made with dendrodated complexes have been quite the contrary.

(C) 2009 by the Arizona Board of Regents on behalf of the University of Arizona

Proceedings of the 5th International ${ }^{14} \mathrm{C}$ and Archaeology Symposium, edited by Irka Hajdas et al.

RADIOCARBON, Vol 51, Nr 2, 2009, p 695-710 


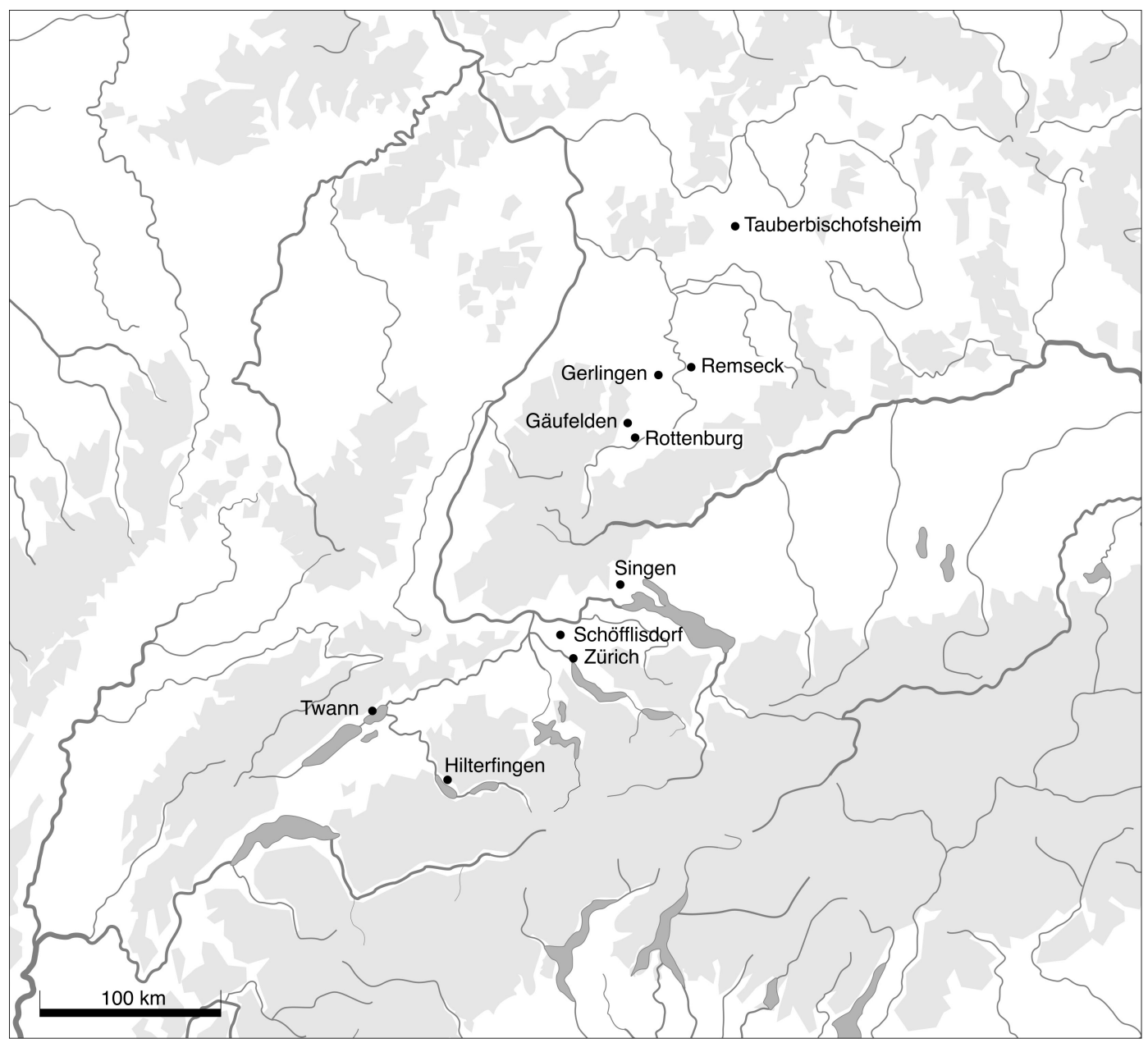

Figure 1 Find locations discussed in the text

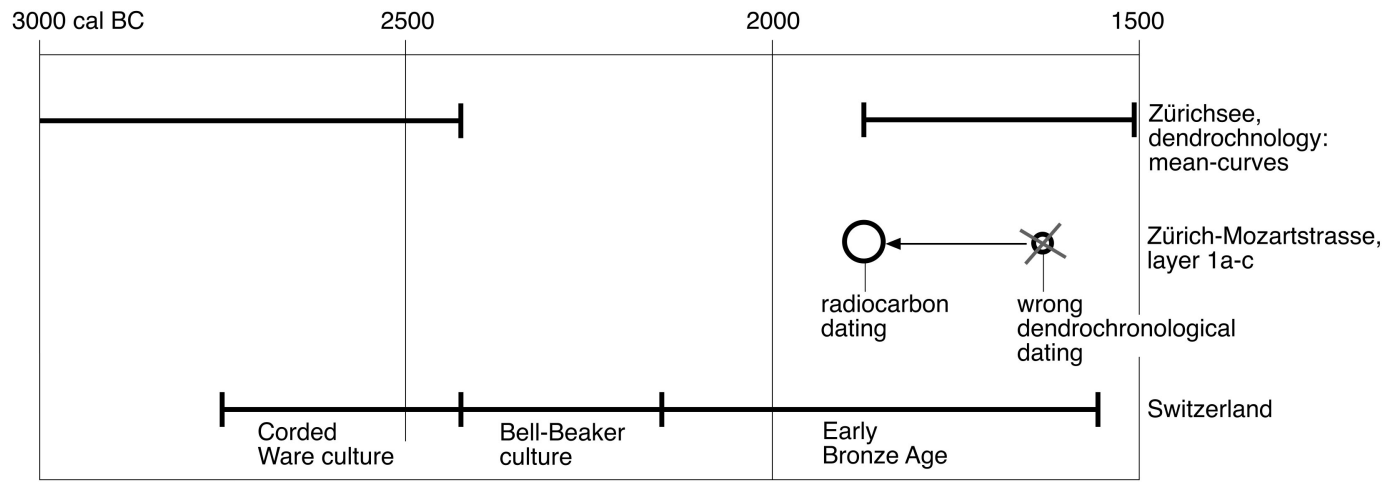

Figure 2 Corrected dating of the settlement Zürich Mozartstrasse in comparison to the dendrochronologcial mean curve from Lake Zürich and the dating of the Corded Ware, Bell Beaker, and Early Bronze Age. 
In 1991, E Gross compared dendrodates and ${ }^{14} \mathrm{C}$ dates from Swiss Neolithic cultures (Figure 3). The dendrodates are shaded in gray. With the exception of Cortaillod and Pfyn, which coexist in the west and east of Switzerland, respectively, the dendrodates are chronologically separable. However, the related, calibrated ${ }^{14} \mathrm{C}$ dates overlap very strongly.

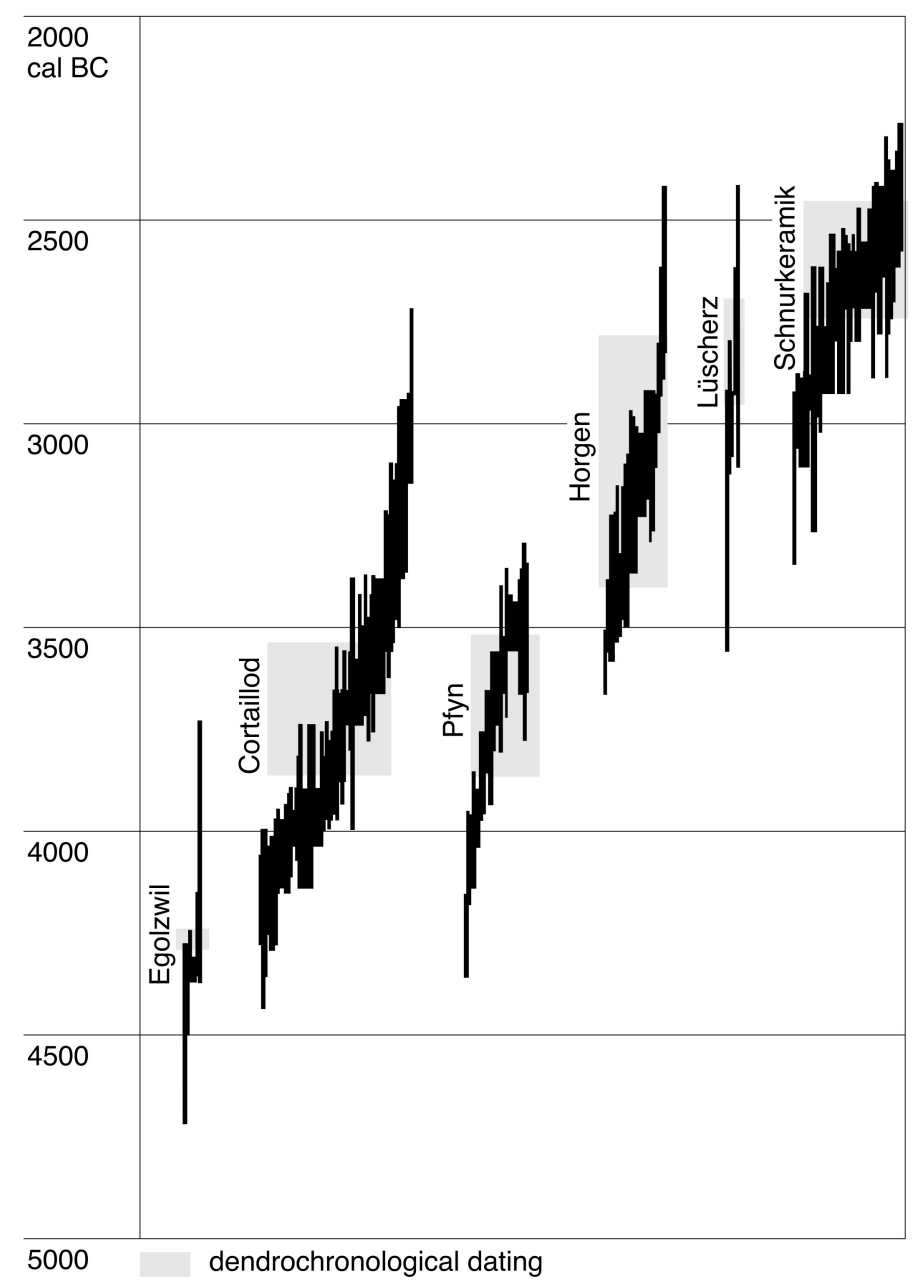

Figure 3 Comparison of the calibrated ${ }^{14} \mathrm{C}$ dates and dendrochronological datings of cultures of the Swiss Neolithic (Ruoff and Gross 1991).

We do not know how many incorrect ${ }^{14} \mathrm{C}$ dates may have crept in via incorrect sampling. This is why I will show the following example: The stratigraphical sequence of the layers US, 3, 5, and 5a from Twann (Stöckli 1990) (Figure 4). You can see the dendrodated blocks of the 4 layers. As there are hardly any ${ }^{14} \mathrm{C}$ dates from Twann, I have selected the ${ }^{14} \mathrm{C}$ dates from the IntCal04 (Reimer et al. 2004) date lists, which correspond with the layers from Twann (Figure 5). This way, we have 4 separate date series, completely free of sampling errors and which can be resolved at a high accuracy unavailable to a normal service. 


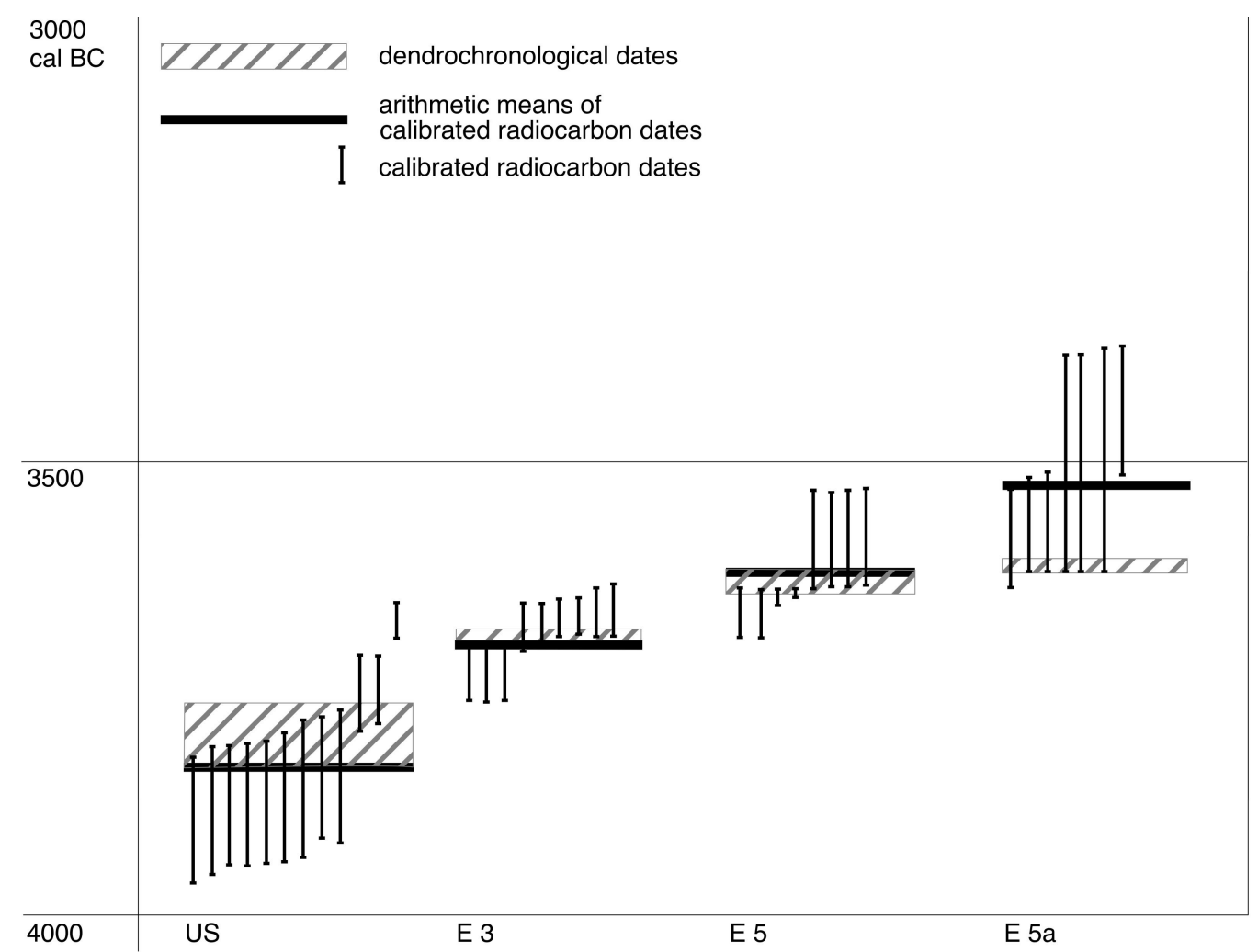

Figure 4 Comparison of the calibrated ${ }^{14} \mathrm{C}$ dates and dendrodates of stratigraphically separate settlement layers from Twann

Overlaps of the calibrated ${ }^{14} \mathrm{C}$ dates are caused by the system of ${ }^{14} \mathrm{C}$ dating, even though the layers were separated by gaps in the settlement (Figure 4). Depending on the movement of the calibrated curve, the mean value of the calibrated ${ }^{14} \mathrm{C}$ dates falls in the region of the dendrodates or it lies outside of it, like ensemble 5a. This is because of the large wiggle around $3600 \mathrm{BC}$ (Figure 5).

Moving to the sequence of Corded Ware-Bell Beaker-Early Bronze Age, we want to note that ${ }^{14} \mathrm{C}$ dating is not in the position to prove a mutual overlapping of cultures. The chronological gap in the dendrodates from Switzerland leaves enough room to fit the Bell Beaker Age in between the Corded Ware and Early Bronze Age (Figure 2). From the comparison between the dendrodates and the scattering of the ${ }^{14} \mathrm{C}$ dates, I conclude the following: The arithmetic mean should be used for series of ${ }^{14} \mathrm{C}$ dates associated with the same or similar structures, as the mean of the actual ${ }^{14} \mathrm{C}$ dates should be more precise than the calibrated ranges. I accept that errors must be taken into account in the extreme movements of the calibration curve, as the example ensemble 5a from Twann shows. But if one always takes the findings and their finds into account, I believe one can identify these cases.

\section{TAUBERBISCHOFSHEIM}

Let us come to the first problem (Stöckli 2009): Veit Dresely published the data from the Corded Ware cemeteries from the Taubertal Valley in North Württemberg (Dresely 2004). From an archaeotypological point of view, he judged the Corded Ware from the graves as uniform and more or less contemporaneous, and I can only agree with his judgment (Figure 6). The $14{ }^{14} \mathrm{C}$ dates of the laboratories from Köln and Heidelberg stand in contrast to this result. His analysis of these dates pro- 


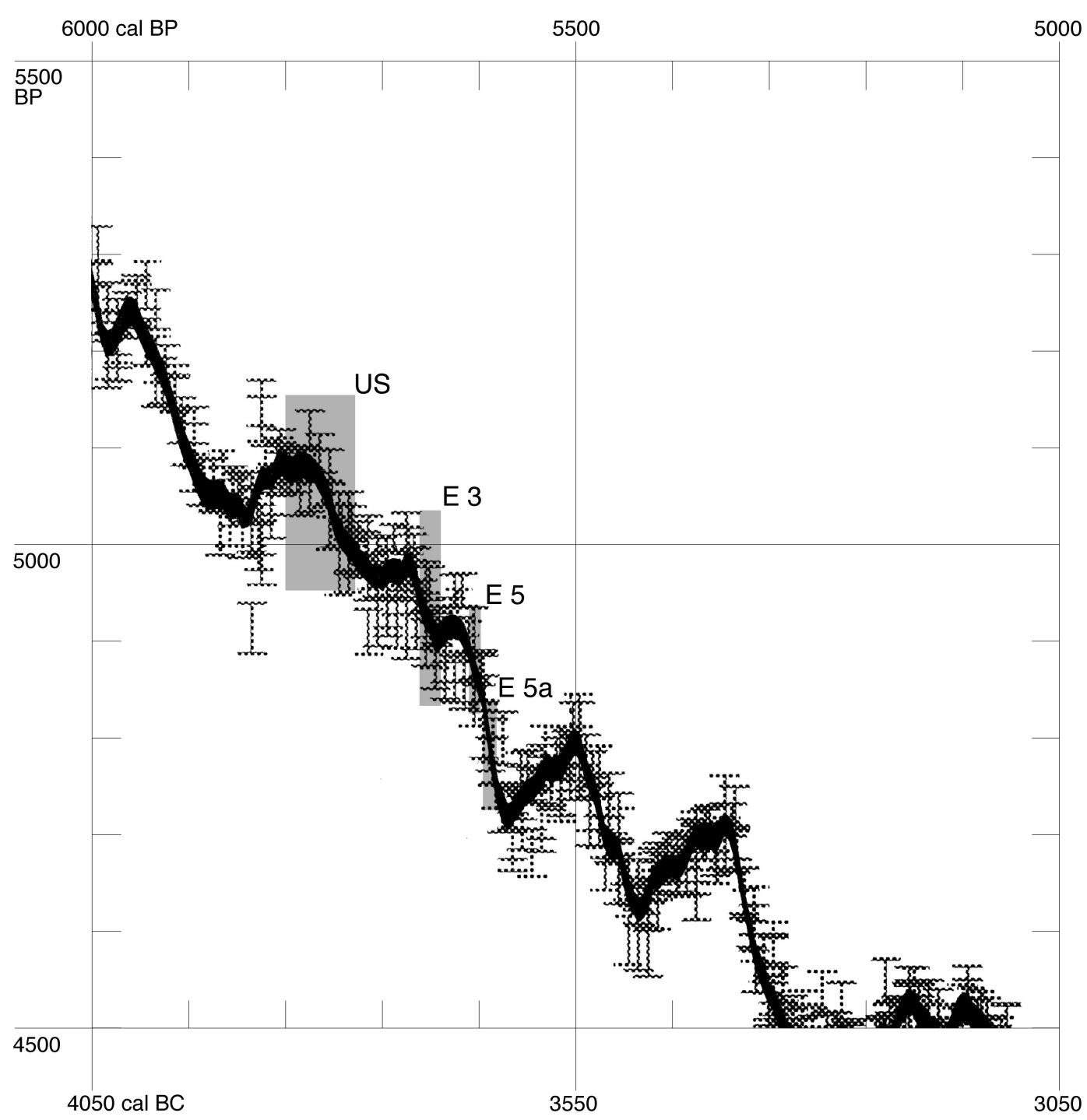

Figure 5 The ${ }^{14} \mathrm{C}$ dates in Figure 4 were selected according to the dendrodates from the layers from Twann

duced a differentiated chronological sequence of the cemeteries in Tauberbischofsheim, which yielded ${ }^{14} \mathrm{C}$ dates. He dates the whole sequence more or less between 2800 and $2100 \mathrm{BC}$. As a consequence, he thus affirms that the material from the Tauber area must be distributed over larger time span than one would assume from the material itself.

Now, we want to take a closer look at the finds and the ${ }^{14} \mathrm{C}$ dates. Figure 6 shows all the complete vessels from the graves of the dated cemeteries from Tauberbischofsheim. The herringbone pattern (Figure 6, \#3) is very common, while the corded pattern is conspicuously rare (Figure 6, \#1). Dresely's uniform results can only be confirmed. On the basis of my own archaeo-typological experiences, a chronological distribution between 2800 and $2100 \mathrm{BC}$ should be ruled out. 


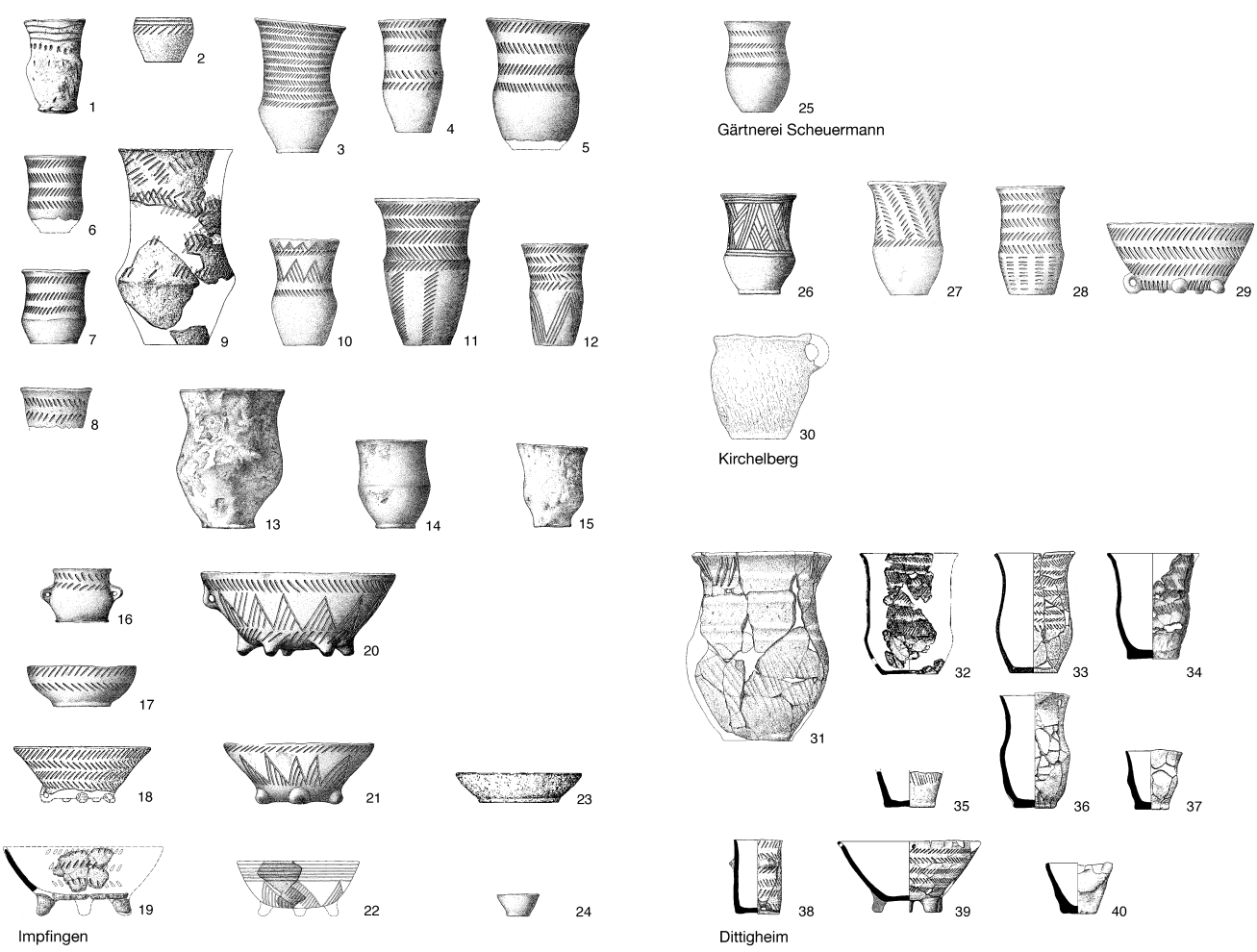

Figure 6 Pottery from the ${ }^{14} \mathrm{C}$-dated cemeteries of Tauberbischofsheim

The ${ }^{14} \mathrm{C}$ dates available must be split into those from the laboratory in Köln and those from Heidelberg (Table 1). The Köln dates were made in the 1970s, those from Heidelberg in the 1990s. The 9 Köln dates have a larger range with a standard deviation of $174{ }^{14} \mathrm{C}$ yr (Table 1,\#1-9). With 6 dates, the cemetery of Impfingen still has a sigma value of $128{ }^{14} \mathrm{C}$ yr (Table 1, \#1-6) and this in a cemetery consisting of only 22 graves with very uniform pottery. If date 6 (Table 1, \#6) is considered as an outlier, it looks somewhat better. We then arrive at $\pm 80{ }^{14} \mathrm{C}$ yr as a standard deviation for the 5 dates. The cemetery at Dittigheim provides us with another 5 dates that were taken by the Heidelberg laboratory in the 1990s (Table 1, \#10-14). These dates have an even smaller range with a standard deviation of $54{ }^{14} \mathrm{C}$ yr. The constitution (Figure 7) and - as we have seen-the finds allow us to compare the cemeteries. Impfingen dates around $2250 \mathrm{BC}$ and Dittigheim around $2470 \mathrm{BC}$, making it around $200 \mathrm{yr}$ older.

Ten of the dated graves from Tauberbischofsheim also contained pottery. I have arranged them by calibrated average dates (Figure 8). If we leave out the youngest grave from Impfingen as an outlier, then the Köln measurements range between 2760 and 2080 BC, those from Heidelberg only between 2520 and $2400 \mathrm{BC}$. According to the Köln Laboratory, the herringbone pattern, so typical for Tauberbischofsheim, is in the 28th, 24th, 22nd, and 21st centuries, while according to the Heidelberg Laboratory (Figure 8, right-hand side), the pattern dates to around $2500 \mathrm{BC}$.

Let us compare the Corded Ware from the Taubertal with the more or less certain development of the Corded Ware in the Swiss Canton of Zurich, which lies about $250 \mathrm{~km}$ to the south (Figure 9). The beakers pictured before $2500 \mathrm{BC}$ are dendrodated, or for after $2500 \mathrm{BC}$ indirectly ${ }^{14} \mathrm{C}$ dated. Despite the large differences, one can still concur with Dresely's archaeo-typological judgment, namely that 
Table 1 Dates of Corded Ware cemeteries from Tauberbischofsheim.

\begin{tabular}{|c|c|c|c|c|}
\hline \# & Site and material & Lab nr & ${ }^{14} \mathrm{C}$ age $\mathrm{BP}$ & $\begin{array}{l}\text { Calibrated } \\
\text { mean }\end{array}$ \\
\hline & Laboratory of Köln & & & \\
\hline 1 & Impfingen, grave 8 , bones & KN-3308 & $3910 \pm 81 \mathrm{BP}$ & - \\
\hline 2 & Impfingen, grave 22 , bones & KN-3309 & $3860 \pm 84 \mathrm{BP}$ & - \\
\hline 3 & Impfingen, grave 7 , bones & KN-3316 & $3820 \pm 84 \mathrm{BP}$ & - \\
\hline 4 & Impfingen, grave 10 , bones & KN-3310 & $3720 \pm 84 \mathrm{BP}$ & - \\
\hline 5 & Impfingen, grave $20 / 1$, bones & $\mathrm{KN}-3312$ & $3700 \pm 78 \mathrm{BP}$ & - \\
\hline 6 & Impfingen, grave $6 / 2$, bones & KN-3311 & $3520 \pm 81 \mathrm{BP}$ & - \\
\hline $1-6$ & Arithmetic mean & - & $3755 \sigma 128 \mathrm{BP}$ & $\sim 2190 \mathrm{cal} \mathrm{BC}$ \\
\hline $1-5$ & Arithmetic mean & - & $3804 \sigma 80 \mathrm{BP}$ & $\sim 2250 \mathrm{cal} \mathrm{BC}$ \\
\hline 7 & Kirchelberg, grave 4 , bones & KN-3315 & $3930 \pm 96 \mathrm{BP}$ & - \\
\hline 8 & Kirchelberg, grave $1 / 1$, bones & KN-3314 & $3830 \pm 88 \mathrm{BP}$ & - \\
\hline $7-8$ & Arithmetic mean & - & $3880 \sigma 50 \mathrm{BP}$ & $\sim 2380$ cal BC \\
\hline 9 & Gärtnerei Scheuermann, grave 2/1, bones & $\mathrm{KN}-3313$ & $4190 \pm 84 \mathrm{BP}$ & $\sim 2760 \mathrm{cal} \mathrm{BC}$ \\
\hline $1-9$ & Arithmetic mean of all cemeteries & - & $3831 \sigma 174 \mathrm{BP}$ & $\sim 2270$ cal BC \\
\hline & Laboratory of Heidelberg & & & \\
\hline 10 & Dittigheim, grave $20 / 1$, bones & Hd-14010-13871 & $4050 \pm 25 \mathrm{BP}$ & - \\
\hline 11 & Dittigheim, grave $17 / 1$, bones & Hd-14009-13748 & $4015 \pm 25 \mathrm{BP}$ & - \\
\hline 12 & Dittigheim, grave $6 / 1$, bones & Hd-14008-13651 & $4010 \pm 45 \mathrm{BP}$ & - \\
\hline 13 & Dittigheim, grave $25 / 3$, bones & Hd-14012-13603 & $3935 \pm 20 \mathrm{BP}$ & - \\
\hline 14 & Dittigheim, grave $21 / 1$, bones & Hd-14011-13896 & $3905 \pm 50 \mathrm{BP}$ & - \\
\hline $10-14$ & Arithmetic mean & - & $3983 \sigma 54 \mathrm{BP}$ & $\sim 2470 \mathrm{cal} \mathrm{BC}$ \\
\hline
\end{tabular}
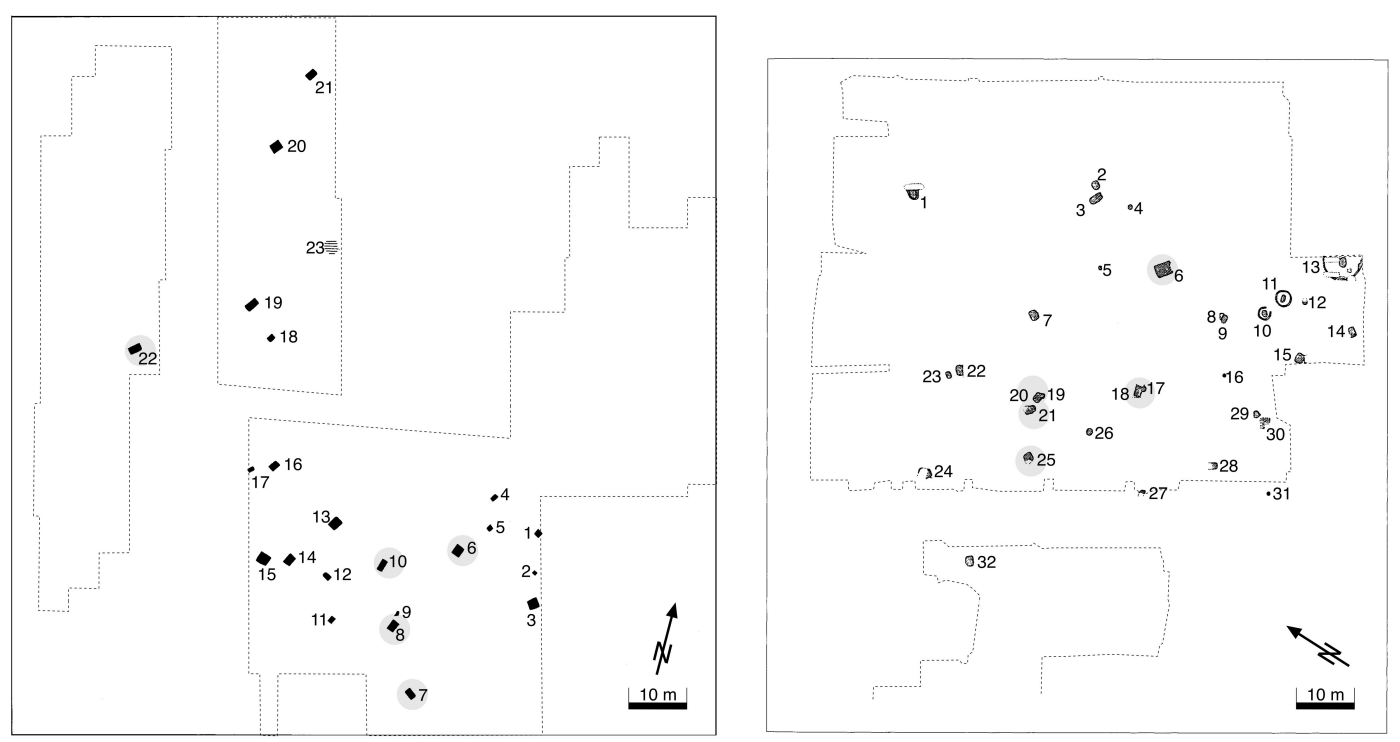

Figure 7 The 2 large cemeteries from Tauberbischofsheim with the ${ }^{14} \mathrm{C}$-dated graves. Shaded circles: dated graves.

we are dealing with a late Corded Ware in the Taubertal. Irrespective of the large differences, the Corded Ware's speed of development in Canton Zurich between 2750 and 2550 can be reasonably adjusted thanks to the dendrodates. This is why I think that a distribution of uniform Corded Ware in the Taubertal of over $700 \mathrm{yr}$ between 2800 and $2100 \mathrm{BC}$, as Dresely intends on the basis of ${ }^{14} \mathrm{C}$ dates from the Köln Laboratory, is impossible. 
Laboratory of Köln

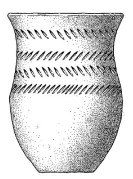

$\sim 2760$ cal BC

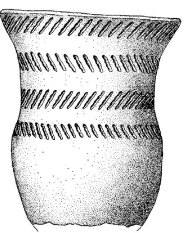

$\sim 2380$ cal BC

1210
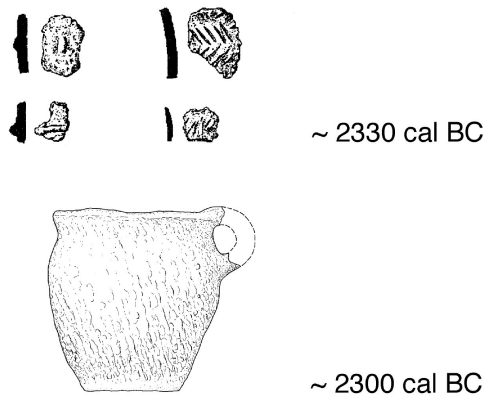

$\sim 2300$ cal BC

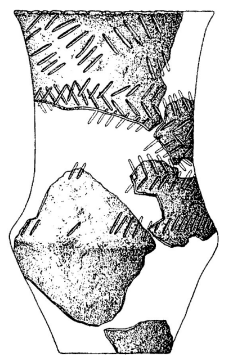

2130 cal BC
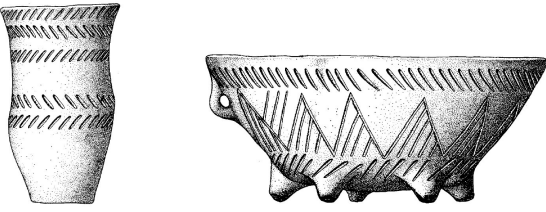

$\sim 2080$ cal BC

$\sim 1840$ cal BC

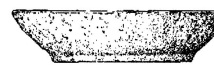

Laboratory of Heidelberg

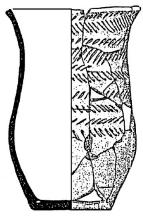

$\sim 2520$ cal BC

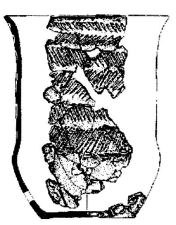

$\sim 2520$ cal BC

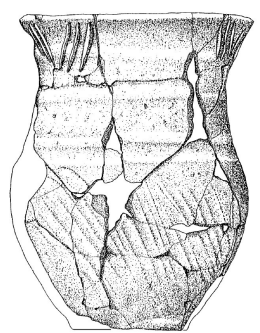

$\sim 2400$ cal BC

Figure $8{ }^{14} \mathrm{C}$-dated pottery from the cemeteries of Tauberbischofsheim separated by the dates from Köln and Heidelberg 


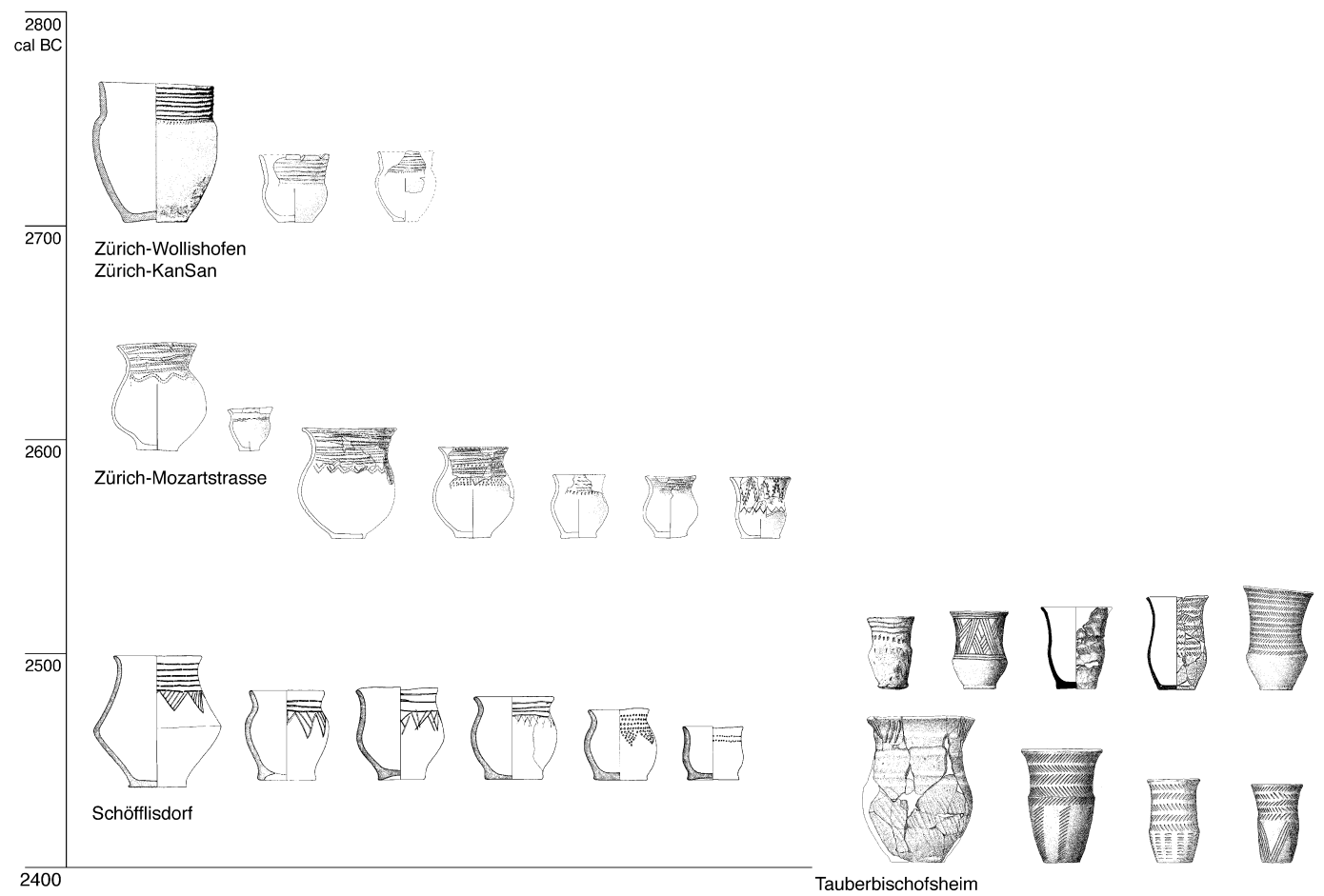

Figure 9 Comparison of dendrodated Corded Ware of Zürich-Wollishofen (Hardmeyer and Ruoff 1983), Zürich-KanSan (Bleuer et al. 1993), and Zürich Mozartstrasse (Gross et al. 1992) with pottery of Schöfflisdorf (Strahm 1971) and Tauberbischofsheim (Dresely 2004).

The case of the Corded Ware from the Taubertal Valley shows that archaeologists are surprisingly quick to question their relative chronology and their own methods. In doing so, they accept ${ }^{14} \mathrm{C}$ dates unconditionally. In the case at hand, the Köln dates can be rejected thanks to the more modern Heidelberg measurements, and already the contradictions between archaeo-typological and ${ }^{14} \mathrm{C}$ dating disappear.

\section{EARLY BRONZE AGE IN BADEN-WÜRTTEMBERG}

Staying in Baden-Württemberg, let us look at the dates from the Early Bronze Age. We begin at the cemetery in Singen, which is the best published (Krause 1988a). One date is clearly too young; the others have only a small span with a standard deviation of $63{ }^{14} \mathrm{C}$ yr (Table 2). Nonetheless, one must ask the question: What sense of reality does the calibrated date range of the mean values have when it spans over $300 \mathrm{yr}$ (Figure 10)? In 1989, Rüdiger Krause took these ranges at face value and attached the dates of the Early Bronze Age cemetery closely to the dendrodates of the Corded Ware (Becker et al. 1989). In this analysis, he would have to remove the Bell Beaker culture completely. In 1996, the Bell Beaker culture exists then in Krause's proposal and the oldest dates from Singen shrink down to an uncertain prolongation of age (Krause 1996).

We now want to study the ${ }^{14} \mathrm{C}$ dates in combination with the finds from the graves (Figure 10). The graves are arranged by the sequence of ${ }^{14} \mathrm{C}$ dates. The large oar needles are conspicuous (Figure 10, $\# 1,15,19)$. They occur in the earliest as well as in much younger graves. Typologically speaking they are so close that one can exclude the large span proposed by the ${ }^{14} \mathrm{C}$ dating results. The com- 
Table 2 Dates from Early Bronze Age cemetery of Singen.

\begin{tabular}{|c|c|c|c|c|}
\hline \# & Site and material & Lab nr & ${ }^{14} \mathrm{C}$ age $\mathrm{BP}$ & Calibrated mean \\
\hline & \multicolumn{3}{|c|}{ Laboratory of Heidelberg } & - \\
\hline 1 & Grave 65 , bones & HD-8974-9155 & $3850 \pm 45 \mathrm{BP}$ & - \\
\hline 2 & Grave 70 , bones & HD-8978-9157 & $3770 \pm 40 \mathrm{BP}$ & - \\
\hline 3 & Grave 19 , bones & HD-8973-9117 & $3760 \pm 50 \mathrm{BP}$ & - \\
\hline 4 & Grave 82 , bones & HD-10691 & $3730 \pm 40 \mathrm{BP}$ & - \\
\hline 5 & Grave 80 , bones & HD-8970-9147 & $3690 \pm 45 \mathrm{BP}$ & - \\
\hline 6 & Grave 7, bones & HD-8972-9116 & $3680 \pm 45 \mathrm{BP}$ & - \\
\hline 7 & Grave 79 , bones & HD-8971-9115 & $3680 \pm 45 \mathrm{BP}$ & - \\
\hline 8 & Grave 63 , bones & HD-10692 & $3655 \pm 35 \mathrm{BP}$ & - \\
\hline 9 & Grave 68 , bones & HD-8975-9145 & $3650 \pm 45 \mathrm{BP}$ & - \\
\hline 10 & Grave 74 , bones & HD-8976-9129 & $3640 \pm 45 \mathrm{BP}$ & - \\
\hline 11 & $\begin{array}{l}\text { Grave number not } \\
\text { published, bones }\end{array}$ & HD-8977-9156 & $2810 \pm 45 \mathrm{BP}$ & - \\
\hline $1-11$ & Arithmetic mean & - & $3629 \sigma 266 \mathrm{BP}$ & $\sim 2040 \mathrm{cal} \mathrm{BC}$ \\
\hline $1-10$ & Arithmetic mean & - & $3710 \sigma 63 \mathrm{BP}$ & $\sim 2090 \mathrm{cal} \mathrm{BC}$ \\
\hline $2-10$ & Arithmetic mean & - & $3695 \sigma 45 \mathrm{BP}$ & $\sim 2060 \mathrm{cal} \mathrm{BC}$ \\
\hline
\end{tabular}

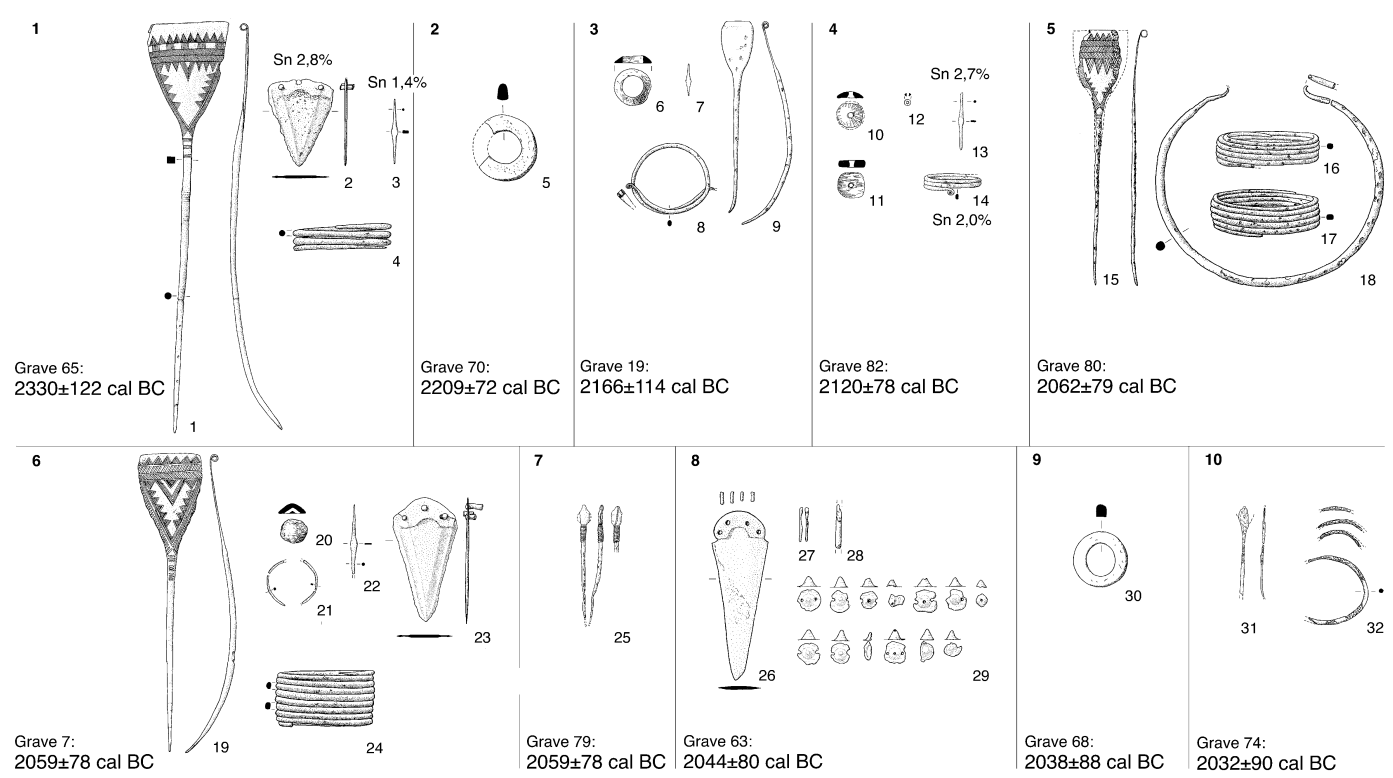

Figure $10{ }^{14} \mathrm{C}$-dated grave ensembles of the Early Bronze Age cemetery of Singen with an indication of tin content over $1 \%$ (Krause 1988a).

parisons between ${ }^{14} \mathrm{C}$ and dendrodating also suggest this conclusion (Figure 3). A detailed comparison also shows that we must view the older dates especially as outliers.

The youngest grave with an oar needle (number 6 ) also contained the oldest dating element: a bone button with a V-shaped hole (Figure 10, \#20). This is very common in the preceding Bell Beaker culture. The oldest grave (number 1), however, contains 2 tin-bronzes, which are a young element, technologically speaking. The horizontal stratigraphical distribution of the dated graves (numbers 1 to 10) does not yield any meaningful sequence (Figure 11), but the tin-bronzes are amassed in the south and are completely absent in the north, where the grave with the button with the V-shaped hole 
lies (number 6). This way, we can conclude that the oldest dated grave is not important for the dating of the cemetery. The second oldest grave (number 2) contains a bone ring with a D-shaped section, a special form of bone ring, which is also the same as the one in the second youngest grave (number 9; Figure 10, \#5, 30). These 2 graves also lie very closely to one another (Figure 11, \#2, 9), and also in an area with a lot of tin-bronze. This means that one must also reject the second oldest ${ }^{14} \mathrm{C}$ date.

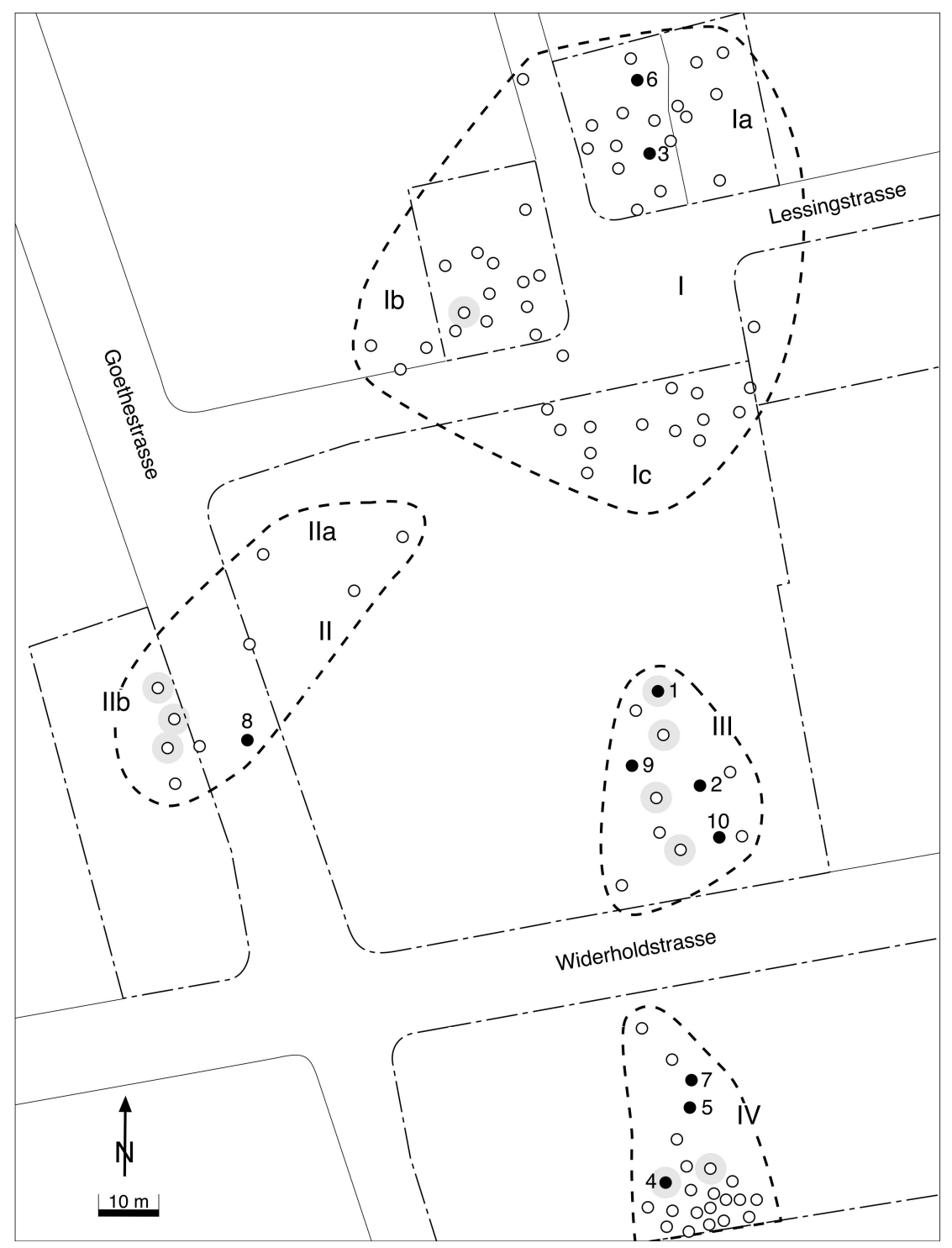

Figure 11 Cemetery of Singen with ${ }^{14} \mathrm{C}$-dated graves (numbers as in Table 2). Shaded circles: graves with artifacts with a tin content over $1 \%$ (Krause 1988a).

It is a matter of taste of how one deals with the remaining 8 dates (Table 2). I would lay the stress on the 6 youngest dates (Table 2, \#5-10; Figure 10, \#5-10), which also lie very closely together and which date the cemetery to the 21 st century $\mathrm{BC}$. We now also have confirmation from Lavagnone to the south of Lake Garda in northern Italy. Here, a log road is dendrochronologically dated to 
$2048 \pm 10 \mathrm{BC}$, and can be associated with material from the Early Bronze Age (de Marinis 2000). This agrees at least to the bone rings with a triangular section in Singen (Figure 10, \#6; Perini 1983). However, this is only a first confirmation, in which I cannot check the dendrodates with respect to the find material.

From an archaeo-typological point of view, 4 cemeteries in the Neckar basin are contemporaneous with Singen (Table 3). The date series from Remseck-Aldingen and Gerlingen correspond in their dates to the 21st century BC-that of Singen-while the date series from Rottenburg and Gäufelden-Tailfingen are about 200 yr younger.

Table 3 Dates of Early Bronze Age cemeteries in the Neckar Valley.

\begin{tabular}{|c|c|c|c|c|}
\hline $\mathrm{Nr}$ & Site and material & Lab nr & ${ }^{14} \mathrm{C}$ age $\mathrm{BP}$ & Calibrated mean \\
\hline & Laboratory of Heidelberg & & & \\
\hline 1 & Remseck-Aldingen, grave 17 , bones & Hd-14083 & $3713 \pm 39 \mathrm{BP}$ & - \\
\hline 2 & Remseck-Aldingen, grave 1 , bones & Hd-14021 & $3710 \pm 37 \mathrm{BP}$ & - \\
\hline 3 & Remseck-Aldingen, grave 12 , bones & Hd-13984 & $3674 \pm 27 \mathrm{BP}$ & - \\
\hline 4 & Remseck-Aldingen, grave 15 , bones & Hd-13744 & $3515 \pm 35 \mathrm{BP}$ & - \\
\hline $1-4$ & Arithmetic mean & - & $3653 \sigma 81 \mathrm{BP}$ & $\sim 2030 \mathrm{cal} \mathrm{BC}$ \\
\hline $1-3$ & Arithmetic mean & - & $3699 \sigma 18 \mathrm{BP}$ & $\sim 2090 \mathrm{cal} \mathrm{BC}$ \\
\hline 5 & Gerlingen, grave 2 , bones & Hd-11872 & $3924 \pm 17 \mathrm{BP}$ & - \\
\hline 6 & Gerlingen, grave $1 / 1$, bones & Hd-11855 & $3684 \pm 16 \mathrm{BP}$ & - \\
\hline 7 & Gerlingen, grave 3 , bones & Hd-11881 & $3646 \pm 21 \mathrm{BP}$ & - \\
\hline 8 & Gerlingen, grave $1 / 2$, bones & Hd-11871 & $3581 \pm 20 \mathrm{BP}$ & - \\
\hline $5-8$ & Arithmetic mean & - & $3708 \sigma 130 \mathrm{BP}$ & $\sim 2110 \mathrm{cal} \mathrm{BC}$ \\
\hline \multirow[t]{2}{*}{$6-8$} & Arithmetic mean & - & $3637 \sigma 43 \mathrm{BP}$ & $\sim 2030 \mathrm{cal} \mathrm{BC}$ \\
\hline & Laboratory of ETH Zürich & & & \\
\hline 9 & Rottenburg, grave 9 , bones & ETH-9562 & $3605 \pm 55 \mathrm{BP}$ & - \\
\hline 10 & Rottenburg, grave 1 , bones & ETH-9555 & $3595 \pm 65 \mathrm{BP}$ & - \\
\hline 11 & Rottenburg, grave 6 , bones & ETH-9560 & $3580 \pm 60 \mathrm{BP}$ & - \\
\hline 12 & Rottenburg, grave 4 , bones & ETH-9558 & $3565 \pm 65 \mathrm{BP}$ & - \\
\hline 13 & Rottenburg, grave 10 , bones & ETH-9563 & $3550 \pm 65 \mathrm{BP}$ & - \\
\hline 14 & Rottenburg, grave 2 , bones & ETH-9556 & $3540 \pm 65 \mathrm{BP}$ & - \\
\hline 15 & Rottenburg, grave 5 , bones & ETH-9559 & $3510 \pm 80 \mathrm{BP}$ & - \\
\hline 16 & Rottenburg, grave 7 , bones & ETH-9561 & $3505 \pm 60 \mathrm{BP}$ & - \\
\hline \multirow[t]{2}{*}{$9-16$} & Arithmetic mean & - & $3556 \sigma 35 \mathrm{BP}$ & $\sim 1860 \mathrm{cal} \mathrm{BC}$ \\
\hline & Laboratory of Heidelberg & & & \\
\hline 17 & Gäufelden-Tailfingen, grave 3, bones & Hd-11854 & $3509 \pm 20 \mathrm{BP}$ & - \\
\hline 18 & Gäufelden-Tailfingen, grave $1 / 2$, bones & Hd-11811 & $3483 \pm 19 \mathrm{BP}$ & - \\
\hline 19 & Gäufelden-Tailfingen, grave $1 / 1$, bones & Hd-11794 & $3455 \pm 33 \mathrm{BP}$ & - \\
\hline $17-19$ & Arithmetic mean & - & $3482 \sigma 22 \mathrm{BP}$ & $\sim 1820 \mathrm{cal} \mathrm{BC}$ \\
\hline
\end{tabular}

Let us take a closer look at the grave goods. The 2 oar needles and the bone rings with triangular section from Remseck-Aldingen fit well to Singen (Krause 1988b), whereas the male graves from Gerlingen pose more problems (Zürn 1975). However, the flat daggers with 3 rivets can be easily synchronized with Singen, where $45 \%$ of the daggers have 3 rivets. In the younger dated cemeteries of Rottenburg (Reim 1997) and Gäufelden-Tailfingen (Becker et al. 1989), once again, the oar needle and the bone ring with a triangular section appear, next to them a necklace that occurs 7 times in Singen. From an archaeo-typological point of view, I find it impossible to distribute these cemeteries over a period of over $200 \mathrm{yr}$, meaning the young dates for Rottenburg and Gäufelden-Tailfingen must be wrong. However, I cannot ignore the fact that the next typological stage is absent in the 
cemeteries found in Baden-Württemberg. This is the reason why in some approaches, archaeologists prolong the dating of the older cemeteries on the basis of ${ }^{14} \mathrm{C}$ dates. I know of 2 graves from Hilterfingen in the Bernese Oberland with typologically younger grave goods, which were dated by the ETH to the 20th and 19th century BC as one would expect (Hafner and Suter 1997).

In Figure 12, I have compared the 2 biggest and best dates sequences from Singen and Rottenburg. The cemeteries are archaeologically contemporaneous, but the ${ }^{14} \mathrm{C}$ dates do not overlap at all and the course of the calibration curve only has small wiggles in this period with a smooth movement. In my opinion, this is a case where new samples must be taken, prepared, and dated, and this must be carried out by separate laboratories, in order to minimize any errors, which might occur in one of the processes. Two separate laboratories are always necessary, because-to my knowledge- the ${ }^{14} \mathrm{C}$ community does not compare the laboratory results of bone data.

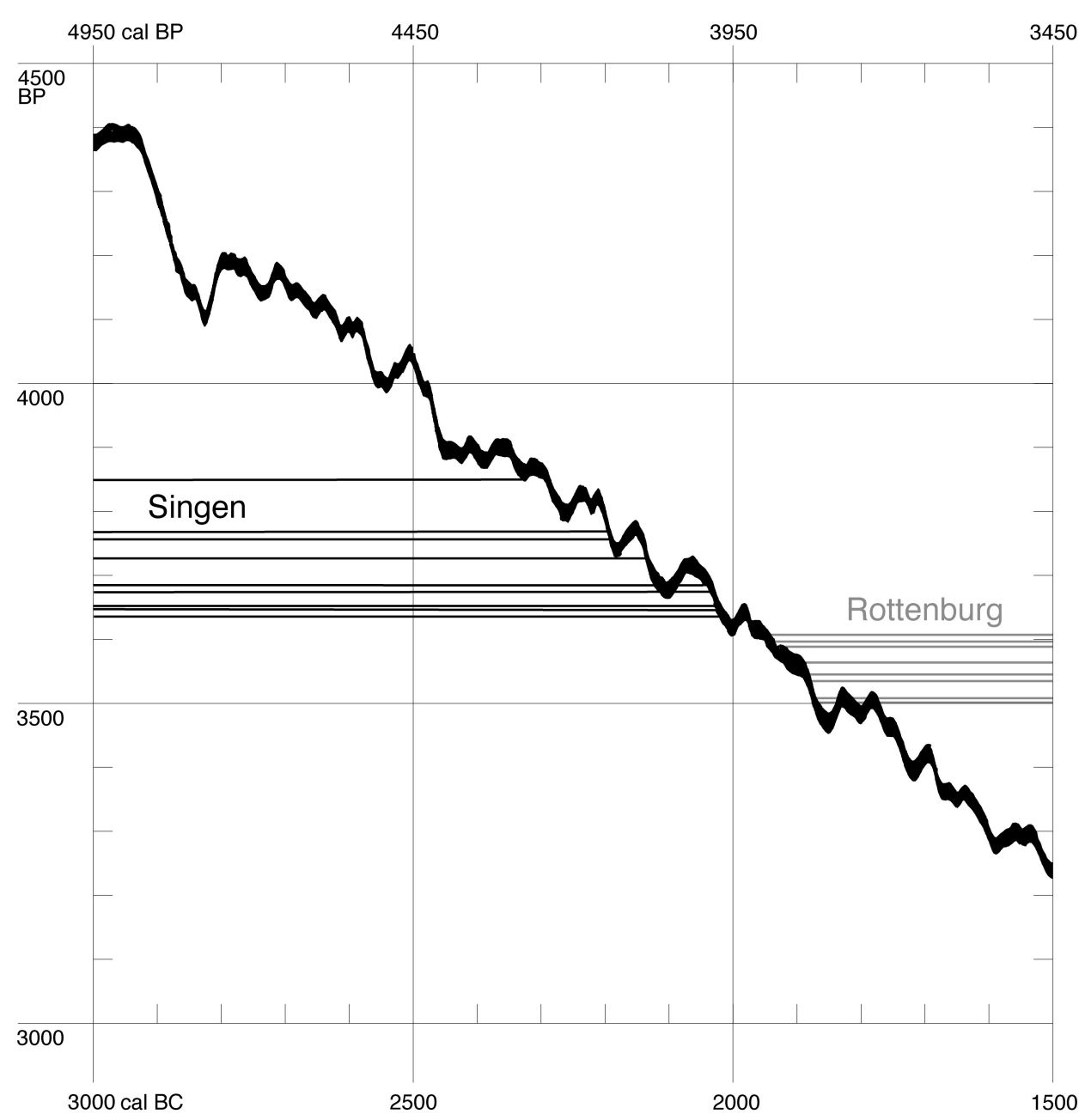

Figure $12{ }^{14} \mathrm{C}$ data series of the Early Bronze Age cemeteries of Singen and Rottenburg in comparison

Here, a close cooperation between archaeologists and ${ }^{14} \mathrm{C}$ experts is necessary. It is a stumbling block that some archaeological partners are not more critical of the dates that come out of the ${ }^{14} \mathrm{C}$ laboratories, but I cannot change that. If, however, a laboratory suggests considering the $2-\sigma$ calibra- 
tion for a date, then the chronological span is so wide that almost every date can be accepted, and so for archaeologists no reaction is necessary. In the case of date series like Singen and Rottenburg, the $2-\sigma$ calibration is not advisable, especially when one recalls the comparison between ${ }^{14} \mathrm{C}$ dates and dendrodates (Figure 3). There can also be problems in assigning a small dating range because of fluctuations in the calibration curve.

\section{RECOMMENDATIONS}

To conclude, I would like to offer some general recommendations for the cases when contradictions occur between the archaeological and ${ }^{14} \mathrm{C}$ dates. The question is, Who is right: archaeology or ${ }^{14} \mathrm{C}$ dating? Unfortunately, this question cannot ever be answered conclusively.

\section{Archaeology is right:}

In this case, one should not just use the calibrated 2- $\sigma$ value in order to cancel out any contradictions. In ${ }^{14} \mathrm{C}$ data series with a small variation, all from the same archaeological context, one must look for systematic errors in the ${ }^{14} \mathrm{C}$ dating. Such errors must be resolved by physicists or chemists. Sometimes errors can be found in the measurements from different laboratories or between older and newer measurements.

2. ${ }^{14} \mathrm{C}$ dating is right:

a.) In this case, the problems likely occurred on site, meaning the sample provenance must be crossexamined. This is why the sample locations must be exactly documented and published accordingly. Whenever possible, the samples should be taken and published from a context holding objects that can utilized in a typological sense. This is the only way a contradiction between ${ }^{14} \mathrm{C}$ and archaeotypological dating can be identified. This requirement can be easily fulfilled in graves, but the graves in question must contain grave goods. One should take as many samples as possible from the same cemetery.

Settlement finds also require the extraction of a sample series. This way, contradictions in the interpretation of the archaeological context can be identified. Whenever possible, the samples should be taken on short-lived organic material.

b.) The problem lies with the archaeological relative chronology. Each contradiction in the dating should be used in order to check one's own archaeo-typological chronology.

Over $100 \mathrm{yr}$ ago, Paul Reinecke began to arrange the relative chronology of the Bronze and Iron ages in central Europe (Stöckli 2006a,b). Since then, it has been continuously refined. From 1500 $\mathrm{BC}$ onwards, the relative chronology is so fine, that in my view, the ${ }^{14} \mathrm{C}$ methods have not actually made any substantial addition from the Middle Bronze Age to the Late La Tène Age and probably cannot. Only dendrodates will ever intervene with enough precision.

The Early Bronze Age and the Neolithic Age are a completely different case. Here, ${ }^{14} \mathrm{C}$ dates must be implemented for the chronological judgment. However, it is only one of various archaeological categories that can be respected for a relative chronology (Stöckli 2002). The finding takes precedence, connected with the finds, and these well-documented samples are then taken for dendrochronological and ${ }^{14} \mathrm{C}$ dating.

I take the finds from exactly observed find contexts very seriously. This is because in Twann, for example, we were able to build up an internal relative chronology for the Cortaillod and Horgen cultures, even before dendrodates were available. Our chronology did not have to be corrected by den- 
drochronology. Hence, we were more successful than other attempts to build up a relative chronology between the Corded Ware culture and the Early Bronze Age.

Therefore, it is important to emphasize the priceless gain of ${ }^{14} \mathrm{C}$ and dendrodating, which have offered the opportunity for the relative chronology to find gaps in our own knowledge as well as those in the archaeological record.

\section{REFERENCES}

Becker B, Krause R, Kromer B. 1989. Zur absoluten Chronologie der Frühen Bronzezeit. Germania 67: 421-42. In German.

Bleuer E, Gerber Y, Haenicke C, Hardmeyer B, Joos M, Rast-Eicher A, Ritzmann C, Schibler J. 1993. Jungsteinzeitliche Ufersiedlungen im Zürcher Seefeld. Ausgrabungen Kanalisationssanierung 1986-1988 (Zürich Kan. San. Seefeld) 2: Tafeln. Zürich: Berichte der Zürcher Denkmalpflege, Monographien 23. 230 p. In German.

Conscience A-C. 2001. Frühbronzezeitliche Uferdörfer aus Zürich-Mozartstrasse-eine folgenreiche Neudatierung. Jahrbuch der Schweizerischen Gesellschaft für Ur- und Frühgeschichte 84:147-57. In German.

de Marinis RC. 2000. Il Museo Civico Archeologico Giovanni Rambotti, una introduzione alla preistoria del lago di Garda. Desenzano di Garda. 255 p. In Italian.

Dresely V. 2004. Schnurkeramik und Schnurkeramiker im Taubertal. Forschungen und Berichte zur Vor- und Frühgeschichte in Baden-Württemberg 81. Stuttgart: Theiss. 499 p. In German.

Gross E, Bleuer E, Hardmeyer B, Rast-Eicher A, Ritzmann C, Ruckstuhl B, Ruoff U, Schibler J. 1992. Zürich «Mozartstrasse». Neolithische und bronzezeitliche Ufersiedlungen 2: Tafeln. Zürich: Berichte der Zürcher Denkmalpflege, Monographien 17.315 p. In German.

Hafner A, Suter PJ. 1997. Die frühbronzezeitlichen Gräber des Berner Oberlandes. In: Fritsch B, Maute M, Matuschik I, Müller J, Wolf C, editors. Tradition und Innovation. Prähistorische Archäologie als historische Wissenschaft. Festschrift für Christian Strahm. Internationale Archäologie. Studia honoraria 3. Rahden/Westf: Leidorf. p 385-416. In German.

Hardmeyer B, Ruoff U. 1983. Die Tauchausgrabungen in Zürich-«Bad Wollishofen». Jahrbuch der Schweizerischen Gesellschaft für Ur- und Frühgeschichte 66: 17-42. In German.

Krause R. 1988a. Die endneolithischen und frühbronzezeitlichen Grabfunde auf der Nordstadtterrasse von Singen am Hohentwiel. Forschungen und Berichte zur Vor- und Frühgeschichte in Baden-Württemberg 32. Stuttgart: Theiss. 361 p. In German.

Krause R. 1988b. Der Beginn der Metallzeiten. In: Planck D, editor. Archäologie in Württemberg. Stuttgart: Theiss. p 111-39. In German.

Krause R. 1996. Zur Chronologie der frühen und mittleren Bronzezeit Süddeutschlands, der Schweiz und Österreich. Acta Archaeologica 67:73-86. In German.
Pape W. 1979. Histogramme neolithischer ${ }^{14} \mathrm{C}$-Daten. Germania 57:1-51. In German.

Perini R. 1983. Der frühbronzezeitliche Pflug von Lavagnone. Archäologisches Korrespondenzblatt 13: 187-95. In German.

Reim H. 1997. Frühbronzezeitliche Gräber und Funde im Neckartal um Rottenburg. In: Goldene Jahhunderte. Die Bronzezeit in Südwestdeutschland. Stuttgart: Theiss. p 98-101. In German.

Reimer PJ, Baillie MGL, Bard E, Bayliss A, Beck JW, Bertrand CJH, Blackwell PG, Buck CE, Burr GS, Cutler KB, Damon PE, Edwards RL, Fairbanks RG, Friedrich M, Guilderson TP, Hogg AG, Hughen KA, Kromer B, McCormac G, Manning S, Bronk Ramsey C, Reimer RW, Remmele S, Southon JR, Stuiver M, Talamo S, Taylor FW, van der Plicht J, Weyhenmeyer CE. 2004. IntCal04 terrestrial radiocarbon age calibration, 0-26 cal kyr BP. Radiocarbon 46(3):1029-58.

Ruoff U, Gross E. 1991. Die Bedeutung der absoluten Datierung der jungsteinzeitlichen Kulturen in der Schweiz für die Urgeschichte Europas. In: Lichardus J, editor. Die Kupferzeit als historische Epoche. Teil 1. Saarbrücker Beiträge zur Altertumskunde 55. Bonn: Habelt. p 401-20. In German.

Stöckli WE. 1990. Geschichte eines neolithischen Siedlungsplatzes. Die neolithischen Ufersiedlungen von Twann im Kanton Bern. In: Die ersten Bauern 1: Schweiz. Zürich: Schweizerisches Landesmuseum. p 307-10. In German.

Stöckli WE. 2002. Absolute und relative Chronologie des Früh- und Mittelneolithikums in Westdeutschland (Rheinland und Rhein-Main-Gebiet). Basler Hefte zur Archäologie 1. Basel: Archäologie. 142 p. In German.

Stöckli WE. 2006a. On the use of chronology and periodization for European prehistory. In: Symposium: Archaeology in Japan-Upheavals and Continuities. A Japanese-European Discussion. 21-24 November 2004. jdzb documentation 8. München: Iudicium. p 149-77. In German

Stöckli WE. 2006b. Zum Umgang mit Chronologie und Periodisierung in der europäischen Vorgeschichte. In: Symposium: Archaeology in Japan-Upheavals and Continuities. A Japanese-European Discussion. 2124 November 2004. jdzb documentation 7. München: Iudicium. p 161-90. In German.

Stöckli WE. 2009. Chronologie und Regionalität des jüngeren Neolithikums (4300-2400 v. Chr.) im schweizerischen Mittelland, in Süddeutschland und in Ostfrankreich aufgrund der Keramik und der absoluten 
Datierungen ausgehend von den Forschungen in den Feuchtbodensiedlungen der Schweiz. Antiqua 45. Basel: Archäologie Schweiz. 403 p. In German.

Strahm C. 1971. Die Gliederung der schnurkeramischen
Kultur in der Schweiz. Acta Bernensia 6. Bern: Stämpfli. 236 p. In German.

Zürn H. 1975. Gerlingen (Lkr. Leonberg). Fundberichte aus Baden-Württemberg 2:61-2. In German. 